\title{
Predicting shear strength of reinforced concrete slender beams without shear reinforcement using artificial neural networks
}

\author{
Kesme donatısız betonarme narin kirişlerin kesme dayanımının yapay sinir \\ ağları kullanılarak tahmini
}

\author{
Riza Secer Orkun KESKIN ${ }^{1^{*}}$ \\ 1Department of Civil Engineering, Faculty of Civil Engineering, Yildiz Technical University, Istanbul, Turkey. \\ okeskin@yildiz.edu.tr
}

Received/Geliş Tarihi: 22.01.2016, Accepted/Kabul Tarihi: 18.04.2016

* Corresponding author/Yazıșilan Yazar

doi: $10.5505 /$ pajes.2016.42243

Research Article/Araștırma Makalesi

\begin{abstract}
Design codes aim to prevent shear failure of reinforced concrete (RC) beams since it is a brittle failure. An accurate prediction of shear strength is important for a proper design of an $R C$ beam. There exist various equations for predicting the shear strength of $R C$ beams. With increasing computational power, it is possible to develop numerical models delivering more accurate predictions than those equations do. In this paper, an artificial neural network (ANN) model developed for predicting the shear strength of $R C$ slender beams without shear reinforcement is presented. The comparisons of the model with five design code equations and fourteen equations proposed by various researchers are given. The model has a better performance than the considered equations do in predicting the shear strength of the beams considered in this study. A parametric study conducted for investigating the effects of various parameters on the shear strength of RC slender beams without shear reinforcement by using the ANN model is also presented. A significant size effect on the shear strength of RC slender beams without shear reinforcement is observed through the results of the parametric study.
\end{abstract}

Keywords: Artificial neural network, Reinforced concrete, Beam, Shear strength

\section{Introduction}

Design codes require a reinforced concrete (RC) beam to have a shear capacity greater than its flexural capacity to prevent a brittle shear failure. An accurate prediction of shear strength is important for a proper design of an RC beam. Numerous researches have been conducted to understand the shear behavior and predict the shear strength of RC beams since the beginning of the last century. ACI-ASCE Committee 426 [1] published a state-of-the-art report focusing on shear transfer and failure mechanisms in RC structural members. ACI-ASCE Committee 445 [2] presented a detailed review of truss model approaches and related theories for designing RC structural members.

The shear strength of RC beams without shear reinforcement is of interest to this research. It has been a common practice to focus on RC beams without shear reinforcement in order to acquire a better understanding of the shear behavior of $\mathrm{RC}$ beams and the contribution of concrete to the shear strength of $\mathrm{RC}$ beams. There exist many equations in the literature proposed for predicting the shear strength of RC beams without shear reinforcement. The predictions from those equations may not always agree with each other because various approaches based on different underlying theories were used for analytical modelling and different experimental data sets
Öz

Yönetmelikler, betonarme kirișlerin kesmeden kırılmasını gevrek bir kırılma olduğu için önlemeyi amaçlar. Bir betonarme kirişin tasarımı için kesme dayanımının doğru tahmini önemlidir. Betonarme kirișlerin kesme dayanımını tahmin etmek için çeșitli denklemler mevcuttur. Artan hesaplama gücü sayesinde, bu denklemlerin yapabileceğinden daha doğru tahminler verecek nümerik modeller geliştirmek mümkündür. Bu makalede, kesme donatısız betonarme narin kirişlerin kesme dayanımını tahmin etmek için geliștirilmiș bir yapay sinir ağ modeli sunulmuştur. Modelin, beş tane yönetmelik denklemiyle ve farkl araștırmacılar tarafından önerilmiș 14 denklemle karșllaștırmaları verilmiştir. Model, bu çalışmada kullanılan kirişlerin kesme dayanımını tahmin etmekte ele alınan denklemlerden daha iyi performans sergilemiștir. Geliştirilen model kullanılarak çeșitli parametrelerin kesme donatısız betonarme narin kirişlerin kesme dayanımı üzerindeki etkilerini incelemek için yapılan bir parametrik çalıșma da sunulmuştur. Bu parametrik çalışma sonucunda, kesme donatısız betonarme narin kirişlerin kesme dayanımı üzerinde önemli bir boyut etkisi gözlemlenmiştir.

Anahtar kelimeler: Yapay sinir ağı, Betonarme, Kiriș, Kesme Dayanımı

were considered for empirical modelling. With increasing computational power, alternative methods have become available for empirical modelling. One of those is to develop an artificial neural network (ANN), which is able to establish the relationships between the parameters involved without requiring any functional form.

The shear behavior of RC beams has been studied by various researchers using ANNs. Oreta [3], Cladera and Mari [4], El-Chabib et al. [5], Seleemah [6] and Jung and Kim [7] developed ANN models to predict the shear strength of RC slender beams without shear reinforcement. Mansour et al. [8], Cladera and Mari [9], El-Chabib et al. [10] and Abdalla et al. [11] studied the shear strength of RC beams with shear reinforcement using ANNs. Goh [12], Sanad and Saka [13] and Yavuz [14] used ANNs to predict the shear strength of RC deep beams. Perera et al. [15] and Tanarslan et al. [16],[17] focused on the shear strength of RC beams strengthened by means of externally bonded fiber reinforced polymers (FRP).

Other computational techniques have also been used. Cevik and Ozturk [18] and Choi et al. [19] studied the application of neurofuzzy models for predicting the shear strength of RC beams without stirrups. Amani and Moeini [20] developed an ANN model and a model based on fuzzy set theory for predicting the shear strength of RC beams with stirrups and compared the 
models. Nasrollahzadeh and Basiri [21] investigated using fuzzy inference system for predicting the shear strength of RC beams strengthened with FRP bars. Mohammadhassani et al. [22] followed a fuzzy modeling approach for predicting the shear strength of RC deep beams by using the adaptive network based fuzzy inference system. Ashour et al. [23] used genetic programming to develop an empirical model predicting the shear strength of RC deep beams and used the model to study the effects of various parameters on the shear strength of RC deep beams. Perez et al. [24],[25] applied a genetic programming algorithm developed for adjusting existing expressions to the shear design formulation for RC beams without shear reinforcement given by Eurocode 2 [26]. Gandomi et al. developed models by using a genetic programming technique for predicting the shear strength of RC deep beams [27],[28] and the shear strength of slender RC beams without stirrups [29],[30]. Cheng and Cao [31] and Chou et al. [32] proposed an evolutionary adaptive regression model and a nature-inspired metaheuristic regression method, respectively, to estimate the shear strength of RC deep beams. Fiore et al. [33] used a hybrid computational technique that is a combination of a genetic approach and the least squares regression for predicting the shear strength of RC beams without stirrups.

The paper presents an ANN model developed for predicting the shear strength of RC beams without shear reinforcement by using an experimental database consisting of 1082 beams. The model was compared with five design code equations and fourteen equations proposed by various researchers. A parametric study was conducted to study the effects of various parameters on the shear strength of RC beams without shear reinforcement using the ANN model. It is observed that the performance of the ANN model is better than the considered equations and there exists a significant size effect on the shear strength of RC slender beams without shear reinforcement.

\section{ANN model}

An ANN is composed of fundamental processing units referred to as neurons [34],[35]. A neuron processes input received from neighboring neuron (s) and sends output to a neighboring neuron. The output of a typical neuron is simply written in the form

$$
q=f(n),
$$

where $f($.$) is the transfer function, which must be$ differentiable, and $n$ is the net input. Introducing the most common net input function, which is the summation of weighted inputs with the bias, the net input for $j$-th neuron becomes

$$
n=\sum_{i=1}^{S} w_{j, i} p_{i}+b_{j}
$$

where $S$ is the number of input elements, $w_{j, i}, i=1, \ldots, S$, is the weight of $i$-th input element, $p_{i}, i=1, \ldots, S$, is the $i$-th input element and $b_{j}$ is the bias that can be viewed as a weight of a constant input of 1 .

Networks can be constructed in the form of layers consisting of neurons [34],[35]. Multi-layer feed-forward network is the most common type used in engineering applications. It consists of an input layer, one or more hidden layer(s) and an output layer. The input layer transmits input elements received from outside of the network to a hidden layer which processes the received data and passes the processed data to either another hidden layer or the output layer which produces the final output. Multi-layer feed-forward networks are adaptive data driven systems developed in two stages: training and validation. In the training stage, weights and biases are tuned using input data with known output so that the trained network can deliver reliable predictions. The most common learning algorithm used for training ANNs is error back-propagation algorithm. Once the network is trained, its performance is evaluated in the validation stage. For more detailed information regarding to neural networks, the reader may refer to [34],[35].

A multi-layer feed-forward network consisting of an input layer of four neurons, a hidden layer of four neurons and an output layer of a single neuron $(4 * 4 * 1)$ was developed using MATLAB Neural Network Toolbox [35]. The network topology is shown in Figure 1 schematically. The input parameters are concrete compressive strength $f_{c}$, tensile reinforcement ratio $\rho$, shear span-to-depth ratio $a / d$ and effective depth $d$. The output is an estimate of ultimate shear strength $\left(v_{u}\right)$. All neurons use the net input function given by Equation (2). The transfer functions of hidden and output layers are log-sigmoid and linear transfer functions, respectively.

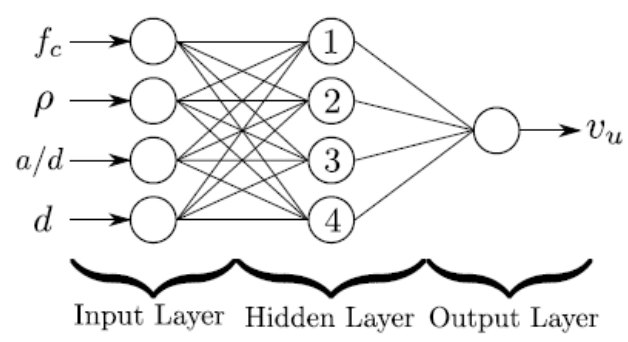

Figure 1: The architecture of the developed ANN model.

The accuracy of predictions of an ANN is based on primarily the data provided to the network for training, which needs to be sufficiently large, accurate and evenly distributed. A database was compiled by selecting slender beams $(a / d \geq 2.5)$ failing in shear from the databases prepared by Reineck et al. [36] and Collins et al. [37], and scanning other experimental studies on RC slender beams without shear reinforcement [38]-[51]. The database includes 1082 beams, where the ranges of parameters are $11.2 \leq f_{c} \leq 127.5(\mathrm{MPa}), \quad 0.14 \% \leq \rho \leq 6.64 \%, \quad 2.5 \leq$ $a / d \leq 8.52,41 \leq d \leq 1400(\mathrm{~mm})$ and $0.25 \leq v_{u} \leq 3.90(\mathrm{MPa})$. It is to be noted that the ANN models developed previously by various researchers [3]-[7] are based on smaller databases, the largest of which contains 523 beams [5]. Considering that the size of database is more than twice the size of the largest one used in the previous studies and the input parameters are fairly distributed, the resulting ANN model is more likely to exhibit a better performance than the ones developed previously. The input parameters were normalized to prevent the log-sigmoid function from becoming saturated which slows down the network training. The shear strength of each beam was also normalized so that a network output fell into the normalized range and then it was converted into the corresponding shear strength.

It is possible for an ANN to memorize the training data and fail to generalize to new data. Early stopping technique was used to improve the generalization. The experimental database was divided into two subsets: training and validation sets. There is no strict rule for determining the sizes of those sets, however 
both of them should be as representative as possible of the whole database. It is a common practice to divide a large part of the whole database as the training set to develop a well generalized ANN model. A similar approach was followed and the database was partitioned into training and validation sets having 974 and 108 beams, respectively. The sets were constructed by a random selection of beams and they were discarded if the constructed sets did not result in a well generalized ANN model. The training set was used to optimize the network performance by tuning the network weights and biases according to the Levenberg-Marquardt backpropagation algorithm [34],[35]. The performance function is the mean squared error (MSE), that is,

$$
F=\frac{1}{N} \sum_{i=1}^{N}\left(t_{i}-q_{i}\right)^{2},
$$

where $N$ is the number of beams, and $t_{i}$ and $q_{i}$ are the experimental and predicted shear strengths of the $i$-th beam, respectively. While training an ANN, the errors on the training and validation sets were monitored simultaneously and the training process was stopped when the error on the validation set started to increase since it is a possible sign of overfitting. The optimum solution was defined at the epoch after which the validation set error failed to decrease for five successive epochs. The resulting errors on the training and validation sets are 0.084 and 0.031 , respectively. Several ANN models resulting in much smaller errors were rejected due to overfitting issues.

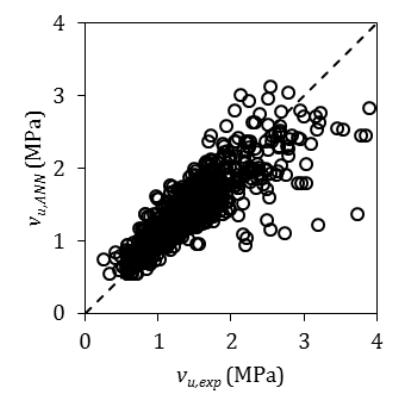

(a): Trainin.g set.

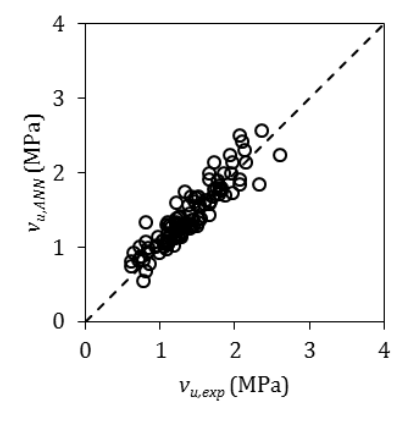

(b): Validation set.

Figure 2: $v_{u, A N N}$ vs. $v_{u, \text { exp }}$.

Table 1: Statistics of $v_{u, A N N}$ vs. $v_{u, \text { exp }}$.

\begin{tabular}{cccccc}
\hline Set & Min. & Max. & Mean & SD & COV \\
\hline Train. & 0.364 & 2.961 & 1.030 & 0.191 & 0.185 \\
Valid. & 0.718 & 1.648 & 1.040 & 0.141 & 0.136 \\
All & 0.364 & 2.961 & 1.031 & 0.186 & 0.181 \\
\hline
\end{tabular}

Figure 2 plots the ANN model outputs $\left(v_{u, A N N}\right)$ against the experimental values $\left(v_{u, \exp }\right)$ for both the training and validation sets. The correlation coefficients are 0.839 and 0.914 , respectively. Table 1 summarizes the statistics of the ratio of the ANN model outputs to the experimental values. The mean, standard deviation (SD) and coefficient of variation (COV) of $v_{u, A N N} / v_{u, \text { exp }}$ for the training set are 1.030, 0.191 and 0.185 , respectively. For the validation set, they are $1.040,0.141$ and 0.136 , respectively. A good agreement between the experimental data and the ANN model outputs is observed through Figure 2 and Table 1.

\section{Comparison with the existing equations}

The model was compared with nineteen equations in total. Five design code equations given by ACI 318 [52], CEB-FIP Model Code [53], Eurocode 2 [26] and TS 500 [54] were considered, where ACI 318 [52] offers a simplified equation as well as a detailed one (Table 2). In addition to the design code equations, fourteen equations proposed by various researchers were considered (Table 3). These are an equation obtained through a multiple regression analysis by Zsutty [55], an empirical equation by Okamura and Higai [56], an equation based on nonlinear fractures mechanics by Bazant and Sun [57], an equation based on basic shear transfer mechanisms, a modified version of Bazant's size effect law and experimental data by Kim and Park [58], an equation resulting from an enhancement of the modified compression field theory by Collins and Kuchma [59], an equation derived through a multiple regression analysis by Rebeiz [60], an equation based on basic principles of mechanics and experimental data by Khuntia and Stojadinovic [61], an equation based on a theory assuming that diagonal tension failure results from a type of splitting of concrete occurring in a certain region of the shear span by Zararis and Papadakis [62], an equation simplified for design purposes by Tureyen and Frosch [63], an equation based on the principal shear strength carried in the compression zone by Arslan [64] and four equations obtained through a genetic programming algorithm adjusting the shear design formulation of Eurocode 2 [26] by Perez et al. [25].

The predictions $\left(v_{u, e q}\right)$ obtained through the equations given in Table 2 and Table 3 against the experimental values are plotted in Figure 3. The statistics of the ratio of the predictions to the experimental values for each equation are given in Table 4. Also, the correlation coefficients $(R)$, the mean squared errors, the normalized mean squared errors (NMSE) and the mean absolute percentage errors (MAPE) for the ANN model and the considered equations are presented in Table 4.

Table 2: Design code equations.

\begin{tabular}{ll}
\hline Design code & Equation \\
\hline ACI 318 [52] & $v_{c}=0.16 \sqrt{f_{c}}+17 \rho\left(\frac{V_{u} d}{M_{u}}\right) \leq 0.29 \sqrt{f_{c}}$, \\
& where $V_{u}$ and $M_{u}$ are the external \\
& factored shear load and bending \\
& moment at the section considered, \\
& respectively, and $V_{u} d / M_{u} \leq 1.0$. \\
ACI 318 [52] & $v_{c}=0.17 \sqrt{f_{c} .}$ \\
CEB-FIP MC [53] & $v_{R d, c}=k_{v} \sqrt{f_{c}}\left(\frac{z}{d}\right), k_{v}=\frac{200}{1000+1.3 z} \leq 0.15$, \\
& $\begin{array}{l}\text { where } z \text { is the internal moment arm } \\
\text { Eurocode 2 [26] can be taken as } 0.9 d .\end{array}$ \\
& $v_{r d, c}=0.18 k\left(100 \rho f_{c}\right)^{\frac{1}{3}} \geq 0.035 k^{\frac{3}{2}} \sqrt{f_{c}}$, \\
TS 500 [54] & where $k=1+\sqrt{200 / d} \leq 2.0, \rho \leq 0.02$. \\
& $v_{c}=0.2275 \sqrt{f_{c} .}$ \\
\hline
\end{tabular}


Table 3: Equations proposed by various researchers.

\begin{tabular}{|c|c|}
\hline Design code & Equation \\
\hline Zsutty [55] & $v_{u}=2.2\left(f_{c} \rho \frac{d}{a}\right)^{1 / 3}$, where $a / d \geq 2.5$ \\
\hline Okamura and Higai [56] & $v_{c}=0.2 \frac{\left(100 \rho f_{c}\right)^{1 / 3}}{d^{1 / 4}}\left(0.75+\frac{1.40}{a / d}\right)$ \\
\hline Bazant and Sun [57] & $v_{u}=0.54 \sqrt[3]{\rho}\left(\sqrt{f_{c}}+249 \sqrt{\frac{\rho}{(a / d)^{5}}}\right)\left(\frac{1+\sqrt{5.08 / d_{a}}}{\sqrt{1+d /\left(25 d_{a}\right)}}\right)$, where $d_{a}$ is the maximum aggregate size in $\mathrm{mm}$. \\
\hline Kim and Park [58] & $\begin{array}{l}v_{u}=3.5 f_{c}^{\alpha / 3} \rho^{3 / 8}\left(0.4+\frac{d}{a}\right)\left(\frac{1}{\sqrt{1+0.008 d}}+0.18\right), \text { where } \alpha=2-(a / d) / 3 \text { for } 1.0 \leq a / d<3.0 \text { and } \\
\alpha=1 \text { for } a / d \geq 3.0 .\end{array}$ \\
\hline Collins and Kuchma [59] & $v_{c}=\frac{245}{1275+\left(\frac{25 S_{X}}{d_{a}+16}\right)} \sqrt{f_{c}}$, where $S_{X} \approx 0.9 d$ \\
\hline Rebeiz [60] & $v_{c}=0.4+\sqrt{f_{c} \rho \frac{d}{a}}\left(2.7-0.4 A_{d}\right)$, where $A_{d}=a / d$ for $a / d<2.5$ and $A_{d}=2.5$ for $a / d \geq 2.5$ \\
\hline Khuntia and Stojadinovic [61] & $v_{c}=0.54 \sqrt[3]{\rho\left(f_{c} \frac{V_{c} d}{M_{u}}\right)^{0.5}}$, where $\frac{M_{u}}{V_{c} d}=\frac{a}{d}-1$ \\
\hline Zararis and Papadakis [62] & $\begin{array}{l}v_{u}=\left(1.2-0.2 \frac{a}{d} d\right) \frac{c}{d} f_{c t} \text {, where } c \text { is the neutral axis depth, } f_{c t}=0.30 f_{c}^{2 / 3} \text { is the splitting tensile } \\
\text { strength of concrete, }(c / d)^{2}+600\left(\rho / f_{c}\right)(c / d)-600\left(\rho / f_{c}\right)=0 \text { and }(1.2-0.2(a / d) d) \geq 0.65 \text {. }\end{array}$ \\
\hline Tureyen and Frosch [63] & $v_{c}=\frac{5}{12} k \sqrt{f_{c}}$, where $k=\sqrt{2 \rho n+(\rho n)^{2}}-\rho n, n=\frac{E_{s}}{E_{c}}, E_{s}=2 \times 10^{5} \mathrm{MPa}, E_{c}=4700 \sqrt{f_{c}}(\mathrm{MPa})$ \\
\hline Arslan [64] & $\begin{array}{l}v_{c}=0.2 f_{c^{\frac{2}{3}}}\left(\frac{c}{d}\right)\left(1+0.032 f_{c^{\frac{1}{6}}}\right)\left(\frac{4}{a / d}\right)^{0.15}\left(\frac{400}{d}\right)^{\frac{1}{4}}, \text { where } a / d \geq 2.5 \text { and } \\
(c / d)^{2}+600\left(\rho / f_{c}\right)(c / d)-600\left(\rho / f_{c}\right)=0\end{array}$ \\
\hline Perez et al. [25] (Eq. 7F1) & $v_{c}=0.1235\left(1+\left(\frac{1600}{d}\right)^{0.40+\frac{f_{c}}{1000}}\right)(100 \rho)^{0.37} f_{c^{\frac{1}{4}}}$ \\
\hline Perez et al. [25] (Eq. 7G1) & $v_{c}=0.094\left(1+\left(\frac{1600}{d}\right)^{0.42}\right)(100 \rho)^{0.37} f_{c^{3}}^{\frac{1}{3}}$ \\
\hline Perez et al. [25] (Eq. 8H1) & $v_{c}=0.114\left(1+\left(\frac{1600}{d}\right)^{0.42}\right)(100 \rho)^{0.37} f_{c}^{\frac{1}{3}}\left(\frac{V d}{M}\right)^{0.21}$. \\
\hline Perez et al. [25] (Eq. 8I1) & $v_{c}=0.114\left(1+\left(\frac{1600}{d}\right)^{0.42}\right)(100 \rho)^{0.37} f_{c}^{\frac{1}{3}}\left(\frac{V d}{M}\right)^{0.21}$. \\
\hline
\end{tabular}

The equations of ACI 318 [52] and CEB-FIP Model Code [53] have a tendency to underestimate the shear strength of the beams in the database while the predictions obtained through the equations of Eurocode 2 [26] and TS 500 [54] are scattered below and above the experimental values. The correlation coefficients between the experimental values and the predictions from the detailed and simplified equations of ACI 318 [52], CEB-FIP Model Code [53], Eurocode 2 [26] and TS 500 [54] are $0.514,0.407,0.538,0.768$ and 0.407 , respectively. The predictions from the considered design code equations except those from the equation of Eurocode 2 [26] are poorly correlated with the experimental values. Among the considered design codes, Eurocode 2 [26] has the best performance in predicting the shear strength of the beams in the database. On the other hand, it is to be noted that the predictions from the equations of ACI 318 [52] and CEB-FIP Model Code [53] are mostly on the safe side.

The predictions obtained through the equations proposed by Collins and Kuchma [59], Rebeiz [60], Khuntia and Stojadinovic [61], Tureyen and Frosch [63] and Arslan [64] are mostly less than the experimental values, where the correlation coefficients are $0.545,0.721,0.734,0.701$ and 0.826 , respectively. On the other hand, the predictions obtained through the equations proposed by Zsutty [55], Okamura and Higai [56], Bazant and Sun [57], Kim and Park [58], and Zararis and Papadakis [62] are scattered below and above the experimental values, where the correlation coefficients are $0.723,0.830,0.824,0.818$ and 0.818 , respectively. The equations 7F1, 7G1, 8H1 and $8 \mathrm{I} 1$ obtained through a genetic programming algorithm by Perez et al. [25] delivers satisfactory predictions with correlation coefficients of 0.791 , $0.794,0.821$ and 0.833 , respectively.

It is observed that the equations proposed by Okamura and Higai [56], Bazant and Sun [57], Kim and Park [58], Zararis and Papadakis [62], Arslan [64] and Perez et al. [25] have better performances in predicting the shear strength of the beams in the database than the other equations do. Compared to the predictions from the considered equations, the ones generated by the ANN model result in smaller errors as can be seen in Table 4. The mean, standard deviation and coefficient of variation of $v_{u, A N N} / v_{u, \exp }$ are $1.031,0.186$ and 0.181 , respectively. The correlation coefficient between the ANN model outputs and the experimental values are 0.844 .

\section{Parametric study}

A parametric study was conducted to study the effects of various parameters on the shear strength of RC slender beams without shear reinforcement using the ANN model. The ranges of parameters were determined in accordance with the ranges available in the database. Figure 4 plots the change in shear strength against effective depth for various values of concrete compressive strength, where tensile reinforcement ratio is $1.0 \%$ and shear span-to-depth-ratio is 3 and 5. Similarly, Figure 5 plots the change in shear strength against effective depth for various values of tensile reinforcement ratio, where concrete compressive strength is $60 \mathrm{MPa}$ and shear span-to-depth-ratio is equal to 3 and 5 . 


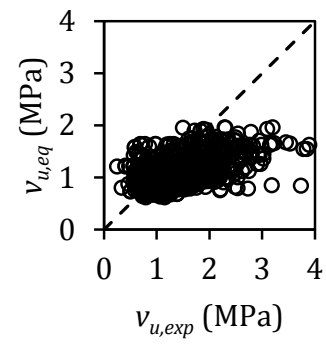

(a): ACI 318 [52].

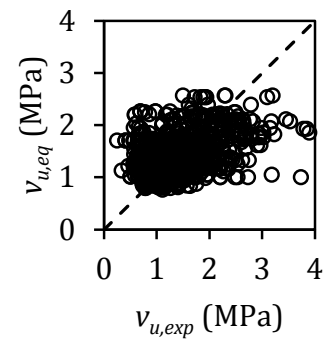

(e): TS 500 [54].

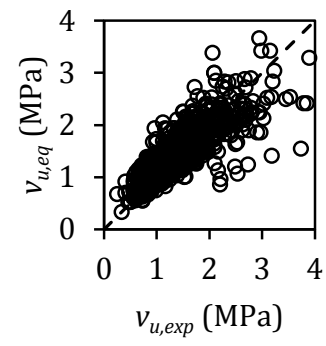

(i): Kim and Park [58].

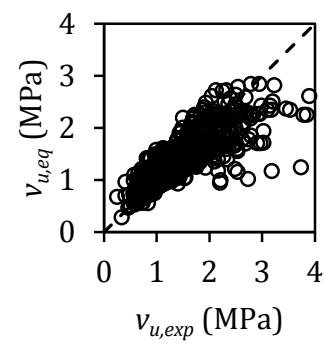

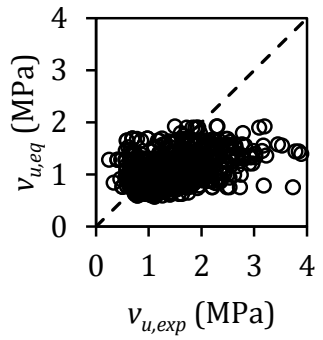

(b): ACI 318 [52] (simplified).

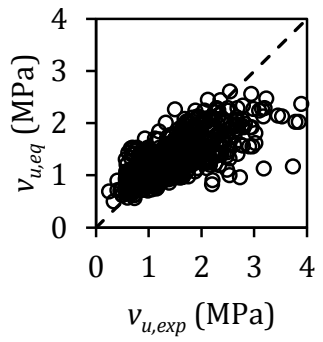

(f): Zsutty [55].

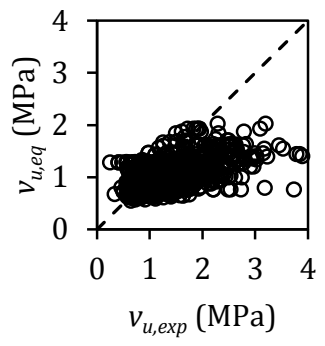

(j): Collins and Kuchma [59].

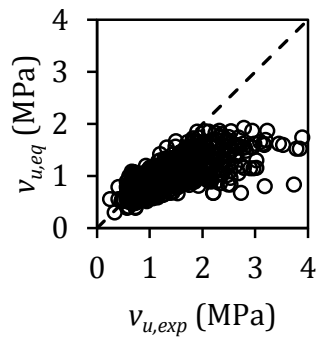

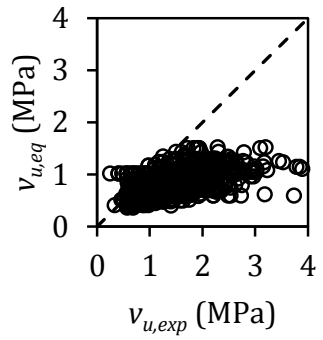

(c): CEB-FIP MC [53].

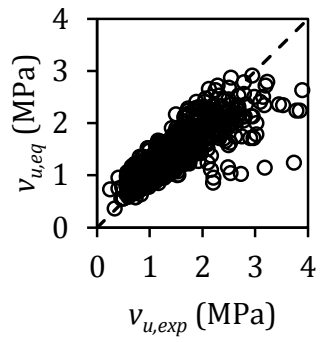

(g): Okamura and Higai [56].

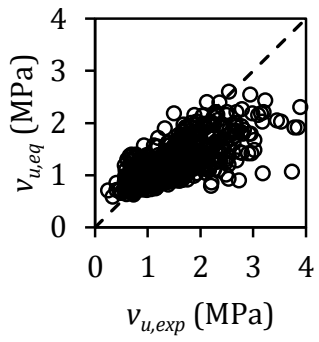

(k): Rebeiz [60].

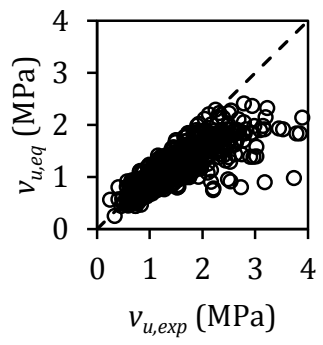

(o): Arslan [64].

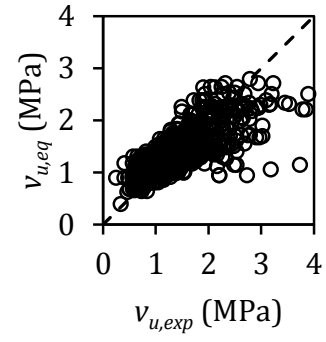

(d): Eurocode 2 [26].

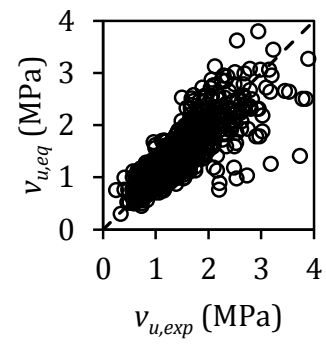

(h): Bazant and Sun [57].

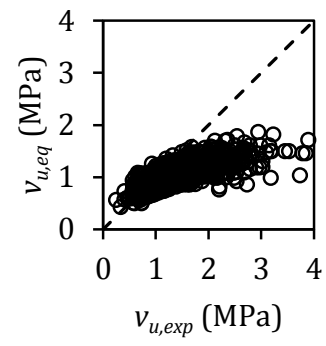

(1): Khuntia and Stojadinovic [61].

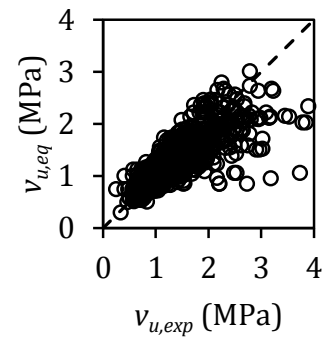

(p): Perez et al. [25] Eq. (7F1).

(m): Zararis and Papadakis [62].

(n): Tureyen and Frosch [63].

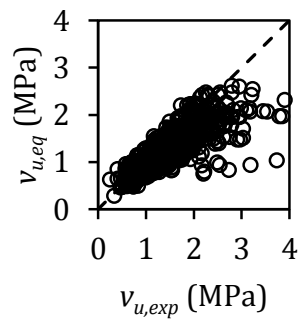

(r): Perez et al. [25] Eq. (8H1).

Figure 3: $v_{u, e q}$ vs. $v_{u, e x p}$.

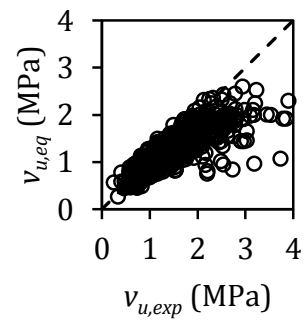

(s): Perez et al. [25] Eq. (8I1).

(q): Perez et al. [25] Eq. (7G1) 
Table 4: Statistics of $v_{u, e q} / v_{u, \text { exp }}$, correlation coefficients and errors for $v_{u, e q} / v_{u, \text { exp }}$.

\begin{tabular}{|c|c|c|c|c|c|c|c|c|c|}
\hline Model/Design code/Author & Min. & Max. & Mean & SD & $\mathrm{COV}$ & $R$ & MSE & NMSE & MAPE \\
\hline The ANN Model & 0.364 & 2.961 & 1.031 & 0.186 & 0.181 & 0.844 & 0.079 & 0.288 & 0.133 \\
\hline ACI 318 [52] & 0.616 & 1.957 & 0.840 & 0.348 & 0.415 & 0.514 & 0.315 & 1.151 & 0.299 \\
\hline ACI 318 [52] (simplified) & 0.569 & 1.920 & 0.817 & 0.374 & 0.458 & 0.407 & 0.371 & 1.356 & 0.329 \\
\hline CEB-FIP Model Code [53] & 0.362 & 1.524 & 0.610 & 0.246 & 0.403 & 0.538 & 0.584 & 2.135 & 0.425 \\
\hline Eurocode $2[26]$ & 0.393 & 2.795 & 1.033 & 0.239 & 0.232 & 0.768 & 0.114 & 0.417 & 0.167 \\
\hline TS $500[54]$ & 0.761 & 2.569 & 1.093 & 0.501 & 0.458 & 0.407 & 0.246 & 0.900 & 0.297 \\
\hline Zsutty [55] & 0.496 & 2.611 & 0.966 & 0.261 & 0.270 & 0.723 & 0.149 & 0.546 & 0.186 \\
\hline Okamura and Higai [56] & 0.368 & 2.917 & 1.008 & 0.196 & 0.194 & 0.830 & 0.087 & 0.319 & 0.134 \\
\hline Bazant and Sun [57] & 0.302 & 3.798 & 1.002 & 0.209 & 0.208 & 0.824 & 0.094 & 0.344 & 0.150 \\
\hline Kim and Park [58] & 0.326 & 4.008 & 1.040 & 0.208 & 0.200 & 0.818 & 0.093 & 0.340 & 0.148 \\
\hline Collins and Kuchma [59] & 0.541 & 2.017 & 0.790 & 0.316 & 0.399 & 0.545 & 0.346 & 1.265 & 0.307 \\
\hline Rebeiz [60] & 0.582 & 2.598 & 0.888 & 0.244 & 0.275 & 0.721 & 0.192 & 0.700 & 0.210 \\
\hline Khuntia and Stojadinovic [61] & 0.426 & 1.860 & 0.796 & 0.203 & 0.254 & 0.734 & 0.293 & 1.069 & 0.250 \\
\hline Zararis and Papadakis [62] & 0.278 & 2.841 & 1.019 & 0.192 & 0.188 & 0.818 & 0.092 & 0.336 & 0.136 \\
\hline Tureyen and Frosch [63] & 0.296 & 1.921 & 0.754 & 0.195 & 0.258 & 0.701 & 0.319 & 1.166 & 0.277 \\
\hline Arslan [64] & 0.250 & 2.406 & 0.837 & 0.155 & 0.186 & 0.826 & 0.168 & 0.612 & 0.190 \\
\hline Perez et al. [25] (Eq. 7F1) & 0.295 & 3.003 & 0.956 & 0.198 & 0.207 & 0.791 & 0.114 & 0.417 & 0.148 \\
\hline Perez et al. [25] (Eq. 7G1) & 0.293 & 2.872 & 0.954 & 0.200 & 0.210 & 0.794 & 0.114 & 0.416 & 0.148 \\
\hline Perez et al. [25] (Eq. 8H1) & 0.282 & 2.618 & 0.884 & 0.170 & 0.192 & 0.821 & 0.131 & 0.479 & 0.164 \\
\hline Perez et al. [25] (Eq. 8I1) & 0.269 & 2.597 & 0.869 & 0.158 & 0.182 & 0.833 & 0.140 & 0.510 & 0.167 \\
\hline
\end{tabular}

Figure 6 depicts the change in shear strength with respect to concrete compressive strength considering shear span-todepth-ratios of 3 and 5, and tensile reinforcement ratios of $0.5 \%, 1.0 \%$ and $1.5 \%$ for an effective depth of $400 \mathrm{~mm}$. Figure 7 presents the change in shear strength against concrete compressive strength considering a tensile reinforcement ratio of $1.0 \%$ and shear span-to-depth-ratios of 3 and 5 for various values of effective depth as 300, 500, 800 and $1200 \mathrm{~mm}$.

Figures 4 and 5 demonstrate the size effect on the shear strength clearly. The reduction in the shear strength ranges from $57 \%$ to $68 \%$ for a tensile reinforcement ratio of $1.0 \%$ as effective depth increases from $41 \mathrm{~mm}$ to $1400 \mathrm{~mm}$, depending on concrete compressive strength and shear span-to-depthratio. It is observed in Figure 4 that the effect of concrete compressive strength diminishes as effective depth gets larger for given tensile reinforcement ratio and shear span-to-depthratio. It should be noted that ACI 318 [52] and TS 500 [54] do not consider size effect in the shear design of RC beams.

It is observed in Figure 6 that shear strength increases with concrete compressive strength for an effective depth of $400 \mathrm{~mm}$ and a shear span-to-depth ratio of 3 and 5. It can be deduced from Figures 5 and 6 that shear strength increases with tensile reinforcement ratio for given concrete compressive strength, shear span-to-depth-ratio and effective depth.

Figure 7 shows that the rate of increase in shear strength with respect to concrete compressive strength decreases as effective depth or shear span-to-depth ratio increases. For instance, shear strength increases by $33 \%$ with an increase of concrete compressive strength from $12 \mathrm{MPa}$ to $127 \mathrm{MPa}$ in case of an effective depth of $800 \mathrm{~mm}$ whereas the increase is $24 \%$ in case of an effective depth of $1200 \mathrm{~mm}$, where tensile reinforcement ratio is $1.0 \%$ and shear span-to-depth ratio is 3 . The increase in shear strength decreases from $24 \%$ to $13 \%$ with an increase in concrete compressive strength from $12 \mathrm{MPa}$ to $127 \mathrm{MPa}$ when shear span-to-depth ratio increases from 3 to 5 for an effective depth of $1200 \mathrm{~mm}$ and a tensile reinforcement ratio of $1.0 \%$. It is observed in Figures 4-7 that shear strength decreases with an increase in shear span-to-depth ratio from 3 to 5 .
A common issue in training an ANN network is the memorization of training data by the network. It is not always possible to detect whether there occurs overfitting or not during training stage, however a network with a poor generalization capability is likely to deliver meaningless solutions during a parametric study, like largely oscillating curves. Since the trends obtained in the parametric study are consistent with the general trends observed in experimental studies, it can be concluded that the developed ANN network is able to generalize to new data within the ranges considered for training the network.

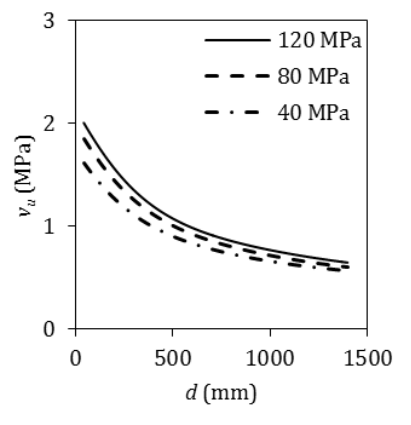

(a): $a / d=3$.

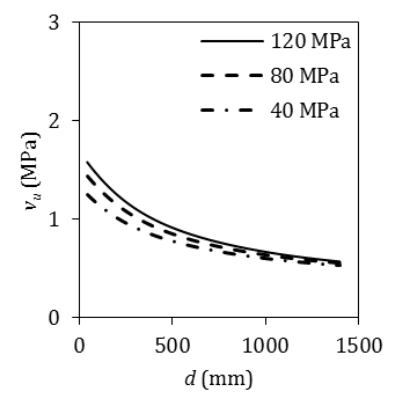

(b): $a / d=5$.

Figure 4: Shear strength vs. effective depth $(\rho=1.0 \%)$. 


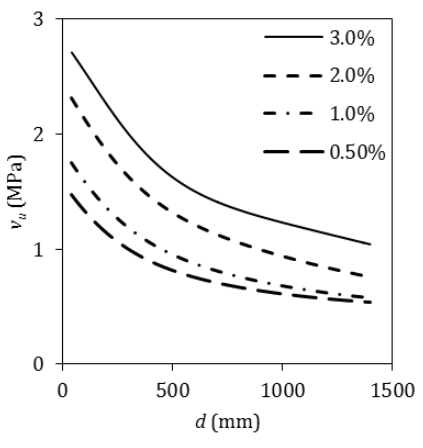

(a): $a / d=3$.

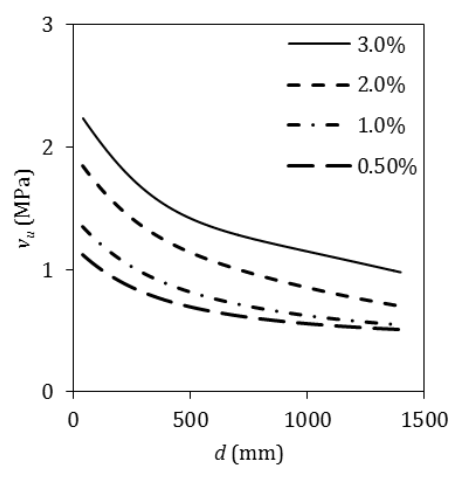

(b): $a / d=5$.

Figure 5: Shear strength vs. effective depth $\left(f_{c}=60 \mathrm{MPa}\right)$.

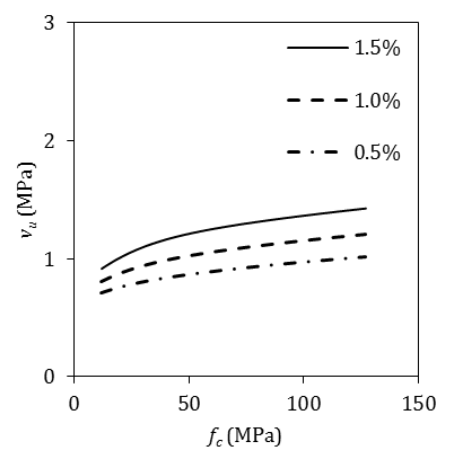

(a): $a / d=3$.

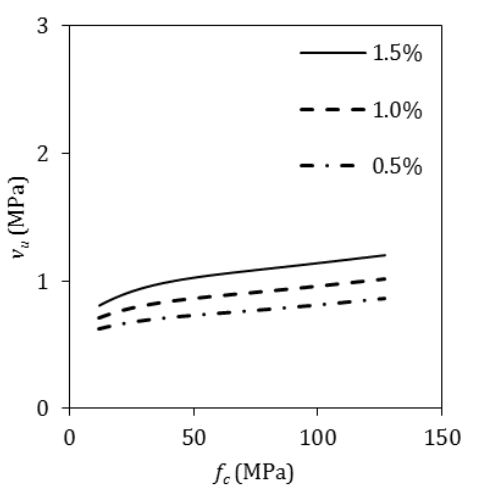

(b): $a / d=5$.

Figure 6: Shear strength vs. concrete compressive strength $(d=400 \mathrm{~mm})$.

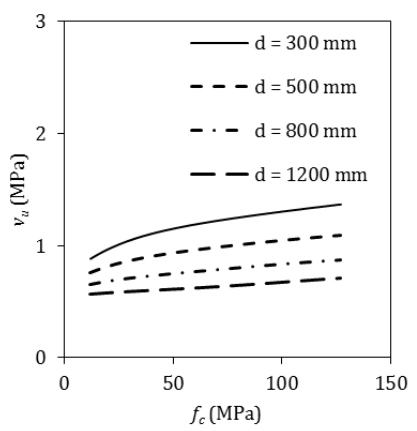

(a): $a / d=3$.

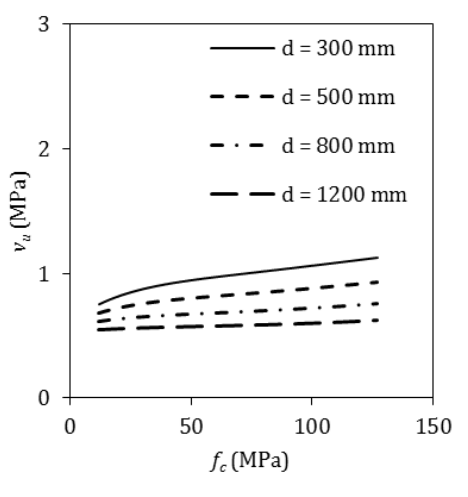

(b): $a / d=5$.

Figure 7: Shear strength vs. concrete compressive strength $(\rho=1.0 \%)$.

\section{Conclusion}

Predicting the shear strength of RC beams is of utmost importance for design purposes since it is required for an RC beam to have shear capacity greater than its flexural capacity in order to avoid a brittle shear failure. An ANN model was developed to predict the shear strength of RC slender beams without shear reinforcement. A database including 1082 beams was used for developing the model consisting of an input layer of four neurons, a hidden layer of four neurons and an output layer of a single neuron. The database is much larger than the ones previously used [3]-[7] for developing ANN models to predict the shear strength of RC slender beams. The input parameters are concrete compressive strength, tensile reinforcement ratio, shear span-to-depth ratio and effective depth. The output is an estimate of shear strength. The mean, standard deviation and coefficient of variation of the ratio of the ANN model outputs to the experimental values are 1.031, 0.186 and 0.181 , respectively. The correlation coefficient between the ANN model outputs and the experimental values is 0.844 . Compared to five design code equations [26],[52]-[54] and fourteen equations [25],[55]-[64] proposed by various researchers, the ANN model has a better performance in predicting the shear strength of the beams in the database. Considering the superior performance of the model over nineteen equations [25],[26],[52]-[64] available in the literature and the size of database more than twice the size of the largest one [5] used for developing ANN models in the previous studies together with fairly distributed input parameters, the ANN model developed in this study can be considered more reliable than the ANN models developed previously. 
A parametric study was performed to investigate the effects of various parameters on the shear strength of RC slender beams without shear reinforcement using the ANN model. It is observed through the parametric study that:

(i)

(iii)
There exists a significant size effect on the shear strength,

Shear strength increases with tensile reinforcement ratio and concrete compressive strength, however the effect of concrete compressive strength diminishes with increasing effective depth, and

An increase in shear span-to-depth ratio from 3 to 5 attenuates the effects of effective depth, concrete compressive strength and tensile reinforcement ratio on the shear strength. Both the performance curves obtained while training the ANN network and the resulting trends observed in the parametric study show that the ANN model is able to generalize to new data. Based on the results of the parametric study, it is recommended to revise the shear design equations of ACI 318 [52] and TS 500 [54] since they do not consider the size effect.

As new data becomes available, the ANN model will be updated to improve its ability of predicting the shear strength of RC slender beams without shear reinforcement.

\section{References}

[1] ACI-ASCE Committee 426 "Shear strength of reinforced concrete members (ACI 426R-74) (Reapproved 1980)". Journal of Structural Division, ASCE, 99(6), 1091-1187, 1973.

[2] ACI-ASCE Committee 445 "Recent approaches to shear design of structural concrete (ACI 445R-99) (Reapproved 2009)". ASCE Journal of Structural Engineering, 124(12), 1375-1417, 1998.

[3] Oreta A. "Simulating size effect on shear strength of RC beams without stirrups using neural networks". Engineering Structures, 26(5), 681-691, 2004.

[4] Cladera A, Mari A. "Shear design procedure for reinforced normal and high strength concrete beams using artificial neural networks. Part I: Beams without stirrups". Engineering Structures, 26(7), 917-926, 2004.

[5] El-Chabib H, Nehdi M, Said A. "Predicting shear capacity of NSC and HSC slender beams without stirrups using artificial intelligence". Computers and Concrete, An International Journal, 2(1), 79-96, 2005.

[6] Seleemah AA. "A neural network model for predicting maximum shear capacity of concrete beams without transverse reinforcement". Canadian Journal of Civil Engineering, 32(4), 644-657, 2005.

[7] Jung S, Kim K. "Knowledge-based prediction of shear strength of concrete beams without shear reinforcement". Engineering Structures, 30(6), 1515-1525, 2008.

[8] Mansour M, Dicleli M, Lee J. "Predicting the shear strength of reinforced concrete beams using artificial neural networks". Engineering Structures, 26(6), 781-799, 2004.

[9] Cladera A, Mari A. "Shear design procedure for reinforced normal and high strength concrete beams using artificial neural networks. Part II: Beams with stirrups". Engineering Structures, 26(7), 927-936, 2004.
[10] El-Chabib H, Nehdi M, Said A. "Predicting the effect of stirrups on shear strength of reinforced normal-strength concrete (NSC) and high-strength concrete (HSC) slender beams using artificial intelligence". Canadian Journal of Civil Engineering, 33(8), 933-944, 2006.

[11] Abdalla J, Elsanosi A, Abdelwahab A. "Modeling and simulation of shear resistance of $\mathrm{R} / \mathrm{C}$ beams using artificial neural network". Journal of The Franklin Institute, 344(5), 741-756, 2007.

[12] Goh A. "Prediction of ultimate shear strength of deep beams using neural networks". ACI Structural Journal, 92(1), 28-32, 1995.

[13] Sanad A, Saka M. "Prediction of ultimate shear strength of reinforced concrete deep beams using neural networks". ASCE Journal of Structural Engineering, 127(7), 818-828, 2001.

[14] Yavuz G. "Shear strength estimation of RC deep beams using the ANN and strut-and-tie approaches". Structural Engineering and Mechanics, 57(4), 657-680, 2016.

[15] Perera R, Barchin M, Arteaga A, Diego AD. "Prediction of the ultimate strength of reinforced concrete beams FRP-strengthened in shear using neural networks". Composites Part B: Engineering, 41(4), 287-298, 2010.

[16] Tanarslan HM, Secer M, Kumanlioglu A. "An approach for estimating the capacity of RC beams strengthened in shear with FRP reinforcements using artificial neural networks". Construction and Building Materials, 30, 556-568, 2012.

[17] Tanarslan HM, Kumanlioglu A, Sakar G. "An anticipated shear design method for reinforced concrete beams strengthened with anchoraged carbon fiber-reinforced polymer by using neural network". The Structural Design of Tall and Special Buildings, 24(1), 19-39, 2015.

[18] Cevik A, Ozturk S. "Neuro-fuzzy model for shear strength of reinforced concrete beams without web reinforcement". Civil Engineering and Environmental Systems, 26(3), 263-277, 2009.

[19] Choi KK, Sherif A, Taha M, Chung L. "Shear strength of slender reinforced concrete beams without web reinforcement: A model using fuzzy set theory". Engineering Structures, 31(3), 768-777, 2009.

[20] Amani J, Moeini R, "Prediction of shear strength of reinforced concrete beams using adaptive neuro-fuzzy inference system and artificial neural network". Scientia Iranica, 19(2), 242-248, 2012.

[21] Nasrollahzadeh K, Basiri MM. "Prediction of shear strength of FRP reinforced concrete beams using fuzzy inference system". Expert Systems with Applications, 41(4), 1006-1020, 2014.

[22] Mohammadhassani M, Saleh AMD, Suhatril M, Safa M. "Fuzzy modelling approach for shear strength prediction of RC deep beams". Smart Structures and Systems, 16(3), 497-519, 2015.

[23] Ashour A, Alvarez L, Toropov V. "Empirical modelling of shear strength of RC deep beams by genetic programming". Computers \& Structures, 81(5), 331-338, 2003.

[24] Perez J, Cladera A, Rabunal J, Martinez-Abella F. “Optimal adjustment of EC-2 shear formulation for concrete elements without web reinforcement using genetic programming". Engineering Structures, 32(11), 3452-3466, 2010. 
[25] Perez J, Cladera A, Rabunal J, Martinez-Abella F. "Optimization of existing equations using a new genetic programming algorithm: application to the shear strength of reinforced concrete beams". Advances in Engineering Software, 50, 82-96, 2012.

[26] European Committee for Standardization. "Eurocode 2: Design of Concrete Structures-Part 1-1: General Rules and Rules for Buildings". Brussels, Belgium, 2004.

[27] Gandomi AH, Yun GJ, Alavi AH. "An evolutionary approach for modeling of shear strength of RC deep beams". Materials and Structures, 46(12), 2109-2119, 2013.

[28] Gandomi AH, Alavi AH, Shadmehri DM, Sahab MG. "An empirical model for shear capacity of RC deep beams using genetic-simulated annealing". Archives of Civil and Mechanical Engineering, 13(3), 354-369, 2013.

[29] Gandomi AH, Alavi AH, Kazemi S, Gandomi M. "Formulation of shear strength of slender RC beams using gene expression programming, part I: Without shear reinforcement". Automation in Construction, 42, 112-121, 2014.

[30] Gandomi AH, Mohammadzadeh D, Pérez-Ordóñez JL, Alavi AH. "Linear genetic programming for shear strength prediction of reinforced concrete beams without stirrups". Applied Soft Computing, 19, 112-120, 2014.

[31] Cheng MY, Cao MT. "Evolutionary multi variate adaptive regression splines for estimating shear strength in reinforced-concrete deep beams". Engineering Applications of Artificial Intelligence, 28, 86-96, 2014.

[32] Chou J, Ngo N, Pham A. "Shear strength prediction in reinforced concrete deep beams using nature-inspired metaheuristic support vector regression". ASCE Journal of Computing in Civil Engineering, 30(1), 2016. doi: 10.1061/(ASCE)CP.1943-5487.0000466

[33] Fiore A, Quaranta G, Marano GC, Monti G. "Evolutionary polynomial regression-based statistical determination of the shear capacity equation for reinforced concrete beams without stirrups". ASCE Journal of Computing in Civil Engineering, 30(1), 2016. doi: 10.1061/(ASCE)CP.19435487.0000450

[34] Hagan M, Demuth H, Beale M. Neural Network Design. Boston, MA, PWS Publishing Company, 1996.

[35] Beale M, Hagan M, Demuth H. MATLAB 2012a Neural Network Toolbox ${ }^{\text {TM }}$ User's Guide. Natick, MA, The MathWorks, Inc., 2012.

[36] Reineck KH, Kuchma D, Kim K, Marx S. "Shear database for reinforced concrete members without shear reinforcement" ACI Structural Journal, 100(2), 240-249, 2003.

[37] Collins M, Bentz E, Sherwood E. "Where is shear reinforcement required? Review of research results and design procedures". ACI Structural Journal, 105(5), 590-600, 2008.

[38] Bohigas A. Shear Design of Reinforced High-Strength Concrete Beams. PhD Thesis, The Polytechnic University of Catalonia, Barcelona, Spain, 2002.

[39] Cho S. "Shear strength prediction by modified plasticity theory for short beams". ACI Structural Journal, 100(1), 105-112, 2003.

[40] Garip E. Shear Strength of Reinforced Concrete Beams Without Stirrups (in Turkish). MSc Thesis, Yildiz Technical University, Istanbul, Turkey, 2011.
[41] Hamrat M, Boulekbache B, Chemrouk M, Amziane S. "Shear behavior of RC beams without stirrups made of normal strength and high strength concretes". Advances in Structural Engineering, 13(1), 29-42, 2010.

[42] Kwak YK, Eberhard M, Kim WS, Kim J. "Shear strength of steel fiber reinforced concrete beams without stirrups". ACI Structural Journal, 99(4), 530-538, 2002.

[43] Lee JY, Choi IJ, Kim SW. "Shear behavior of reinforced concrete beams with high-strength stirrups". ACI Structural Journal, 108(5), 620-629, 2011.

[44] Shah A, Ahmad S. "An experimental investigation into shear capacity of high strength concrete beams". Asian Journal of Civil Engineering (Building and Housing), 8(5), 549-562, 2007.

[45] Slowik M, Nowicki T. "The analysis of diagonal crack propagation in concrete beams". Computational Materials Science, 52, 261-267, 2012.

[46] Slowik M, Smarzewski P. "Study of the scale effect on diagonal crack propagation in concrete beams". Computational Materials Science, 64, 216-220, 2012.

[47] Sneed L, Ramirez J. "Influence of effective depth on shear strength of concrete beams-experimental study". ACI Structural Journal, 107(5), 554-562, 2010.

[48] Taylor R. "Some shear tests on reinforced concrete beams without shear reinforcement". Magazine of Concrete Research, 12(36), 145-154, 1960.

[49] Taylor R, Brewer R. "The effect of the type of aggregate on the diagonal cracking of reinforced concrete beams". Magazine of Concrete Research, 15(44), 87-92, 1963.

[50] Tompos E, Frosch R. "Influence of beam size, longitudinal reinforcement, and stirrup effectiveness on concrete shear strength". ACI Structural Journal, 99(5), 559-567, 2002.

[51] Wafa F, Ashour S, Hasanain G. "Shear behavior of reinforced high strength concrete beams". Engineering Journal of Qatar University, 7, 91-113, 1994.

[52] ACI Committee 318. "Building Code Requirements for Structural Concrete (ACI 318M-11) and Commentary". Farmington Hills, MI, USA, 2011.

[53] Comité Euro-International du Béton. "CEB-FIP Model Code 2010". Lausanne, Switzerland, 2010.

[54] Turkish Standards Institute. "TS 500 Requirements for Design and Construction of Reinforced Concrete Structures". Ankara, Turkey, 2000.

[55] Zsutty T. "Shear strength prediction for separate categories of simple beam tests". ACI Journal Proceedings, 68(2), 138-143, 1971.

[56] Okamura H, Higai T. "Proposed design equation for shear strength of RC beams without web reinforcement". Proceedings, Japan Society of Civil Engineering, 300, 131-141, 1980.

[57] Bazant Z, Sun HH. "Size effect in diagonal shear failure: influence of aggregate size and stirrups". ACI Materials Journal, 84(4), 259-272, 1987.

[58] Kim JK, Park YD. "Prediction of shear strength of reinforced concrete beams without web reinforcement". ACI Materials Journal, 93(3), 213-222, 1996.

[59] Collins M, Kuchma D. "How safe are our large, lightly reinforced concrete beams, slabs and footings?". ACI Structural Journal, 96(4), 482-490, 1999.

[60] Rebeiz K. "Shear strength prediction for concrete members". ASCE Journal of Structural Engineering, 125(3), 301-308, 1999. 
[61] Khuntia M, Stojadinovic B. "Shear strength of reinforced concrete beams without transverse reinforcement". ACI Structural Journal, 98(5), 648-656, 2001.

[62] Zararis P, Papadakis G. "Diagonal shear failure and size effect in RC beams without web reinforcement". ASCE Journal of Structural Engineering, 127(7), 733-742, 2001.
[63] Tureyen A, Frosch R. "Concrete shear strength: another perspective". ACI Structural Journal, 100(5), 609-615, 2003.

[64] Arslan G. "Diagonal tension failure of RC beams without stirrups". Journal of Civil Engineering and Management, 18(2), 217-226, 2012. 